Ann. Biol. anim. Bioch. Biophys., 1978, 18 (2 B), 477-482.

\title{
Role of steroids in the maturation of ovine oocytes
}

\author{
by R. M. MOOR
}

Institute of Animal Physiology, Animal Research Station 307 Huntingdon Road, Cambridge CB3 OJQ, U. K.

Summary. An inductive period of 6-8 $\mathrm{h}$ within the follicle after gonadotrophin treatment is a prerequisite for complete maturation of oocytes in sheep. Steroid function during the inductive phase is characterized by (i) elevated levels of œstrogen (in vitro: $21.0 \mathrm{nmol} / \mathrm{ml}$ follicular fluid ; in vivo: $3.1 \mathrm{nmol} / \mathrm{ml})$, (ii) intermediate levels of androgen $(7.0$ and $3.5 \mathrm{nmol} / \mathrm{ml}$ in vitro and in vivo respectively) and (iii) relatively low levels of progesterone $(0.4$ and $0.8 \mathrm{nmol} / \mathrm{ml}$ in vifro and in vivo respectively).

Steroid support is not required for the breakdown of the germinal vesicle and the formation of the first metaphase plate; a possible involvement of steroids in the later stages of meiotic maturation is suggested.

Substantial levels of steroid, especially œstrogen, are essential for cytoplasmic maturation. Inadequate steroid support during maturation results in anomalies in fertilization, delayed cleavage and an almost total failure to undergo differentiation and blastocyst formation.

\section{Introduction.}

The involvement of steroids in the maturation of mammalian oocytes is the subject of much debate. On the one hand, it has been postulated that steroids are not involved in meiotic maturation since LH initiates meiosis in follicles even after the total suppression of follicular steroidogenesis (Lindner et al., 1974 ; Lieberman et al., 1976). By contrast, other investigators report that steroids stimulate the rate of meiosis (Robertson and Baker, 1969 ; Bae and Foote, 1975), and reduce the incidence of chromosomal abnormality at telophase I and metaphase II (McGaughey, 1977). In addition, steroids have been implicated, together with gonadotrophins, in the induction of cytoplasmic maturation in human, rabbit and sheep oocytes (see Thibault, 1977 ; Moor and Warnes, 1977). These observations accord well with the finding that progesterone and its $17 \alpha-20 \beta$ metabolite are important regulators of oocyte maturation in amphibia and fishes (Schuetz, 1974 ; Smith, 1975 ; Jalabert, 1976).

Two distinct phases occur during the maturation of mammalian oocytes (i) an inductive phase of about 6-8 h in duration which is follicle-dependent and (ii) a synthetic phase which is not dependent upon the follicle (Moor and Warnes, 1977). It is the purpose of this paper both to define the steroid changes that occur in the follicles of sheep during the $6 \mathrm{~h}$ inductive phase and to relate these changes to the nuclear and cytoplasmic events pertaining within the oocyte during maturation. 


\section{Material and methods.}

Non-atretic follicles of between 3.5 and $5.5 \mathrm{~mm}$ in diameter were dissected from the ovaries of Welsh Mountain sheep which had been injected $36 \mathrm{~h}$ previously with 1200 i.u. PMSG. The follicles were placed singly on stainless steel grids in plastic petri dishes according to the method of Moor and Trounson (1977).

To determine the content and pattern of steroids secreted during the inductive phase, follicles were exposed in vitro to $5 \mu \mathrm{g} / \mathrm{ml} \mathrm{NIH-LH}-\mathrm{S} 18$ and the medium changed each hour thereafter. Groups of 7 follicles were removed from culture after each change of medium and opened to obtain samples of follicular fluid for steroid analysis.

Studies on maturation, fertilization and development were carried out on oocytes cultured within the follicles (intrafollicular oocytes) since almost all extrafollicular oocytes undergo abortive maturational change in vitro. An analysis of the published results (comprising over 1500 oocytes from mouse, rabbit, sheep and cow) show that 40-60 p. 100 of intrafollicular oocytes and less than 1 p. 100 of extrafollicular oocytes develop into normal fetuses when transferred after culture to recipient females (Moor and Warnes, 1977). In the present study oocytes were removed from follicles after $24 \mathrm{~h}$ in vitro and transferred directly to the oviducts of inseminated sheep in œstrus. Oocytes were recovered $24 \mathrm{~h}$ after transfer for fertilization studies and after 7 days for studies on embryonic development and differentiation.

Steroids were extracted from the follicular fluid and culture medium with redistilled diethyl ether. The concentration of unconjugated œstrogen, testosterone and progesterone in the ether extracts was measured by radioimmunoassay using the same antisera and methodology as that described previously (Moor, 1977). The limit of sensitivity and the between-assay coefficient of variation for the assays was, for œstrogen $10 \mathrm{pg} / \mathrm{ml}$ and 7 p. 100 , testosterone $15 \mathrm{pg} / \mathrm{ml}$ and 8 p. 100 and progesterone $30 \mathrm{pg} / \mathrm{ml}$ and $12 \mathrm{p} .100$.

\section{Results.}

Steroid production after $\mathrm{LH}$.

Changes in the concentration and rate of secretion of œstrogen, testosterone and progesterone during the first $6 \mathrm{~h}$ after $\mathrm{LH}$ stimulation in vitro is shown in figure 1. The principal features of steroidogenesis in culture were (i) the steady increase in the intrafollicular concentration of œstrogen and androgen throughout the $6 \mathrm{~h}$ after $\mathrm{LH}$, and (ii) the rapid rise over the first $2 \mathrm{~h}$ and the subsequent decline in the secretion of those steroids into the culture medium. Corresponding measurements of steroid content in preovulatory follicles in vivo showed that total intrafollicular steroid concentrations reached maximal levels of $7.5 \mathrm{nmol} / \mathrm{ml}$ follicular fluid within $60-90 \mathrm{~min}$ of LH administration. At that time cstrogen accounted for 40 p. 100, testosterone 27 p. 100 , androstenedione 22 p. 100 and progesterone 11 p. 100 of the total steroid (see fig. 1 for the comparative steroid profile in vitro). Within $6 \mathrm{~h}$ of the administration of $\mathrm{LH}$ in vivo, total steroid concentration had declined to $3.2 \mathrm{nmol} / \mathrm{ml}$; by $6 \mathrm{~h}$ post $\mathrm{LH}$ œstrogen accounted for only 2 p. 100 of the total intrafollicular steroid content while the proportion of androgen had increased to 79 p. 100 . At $12 \mathrm{~h}$ after $\mathrm{LH}$, œstrogen 
and androgen together accounted for about 23 p. 100 of the total steroid in the follicular fluid ; progesterone levels, which were low during the first $6 \mathrm{~h}$ in vivo, formed 77 p. 100 of the follicular fluid steroid by $12 \mathrm{~h}$ after LH.

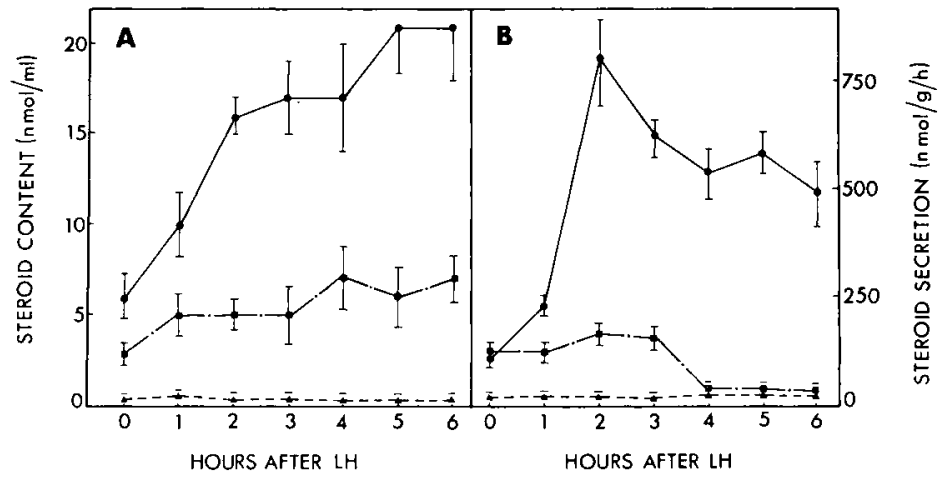

FIG. 1. - The concentration (fig. $1 A$ ) and rate of secretion (fig. 1B) of œsiradiol-17 $\beta(\bullet-\bullet)$, testosterane (-_-_- and progesterone (_-...-A) by ovine follicles exposed to $5 \mu \mathrm{g} \mathrm{NIH-LH-S18/m/} \mathrm{in} \mathrm{vitro.}$ Vertical bars represent standard error of mean (SEM).

Steroids and meiotic maturation.

The effect of gonadotrophin and œstradiol-17 $\beta$ on the proportion of oocyles tha reached metaphase II after $24 \mathrm{~h}$ of culture within intact follicles is shown in figure 2.

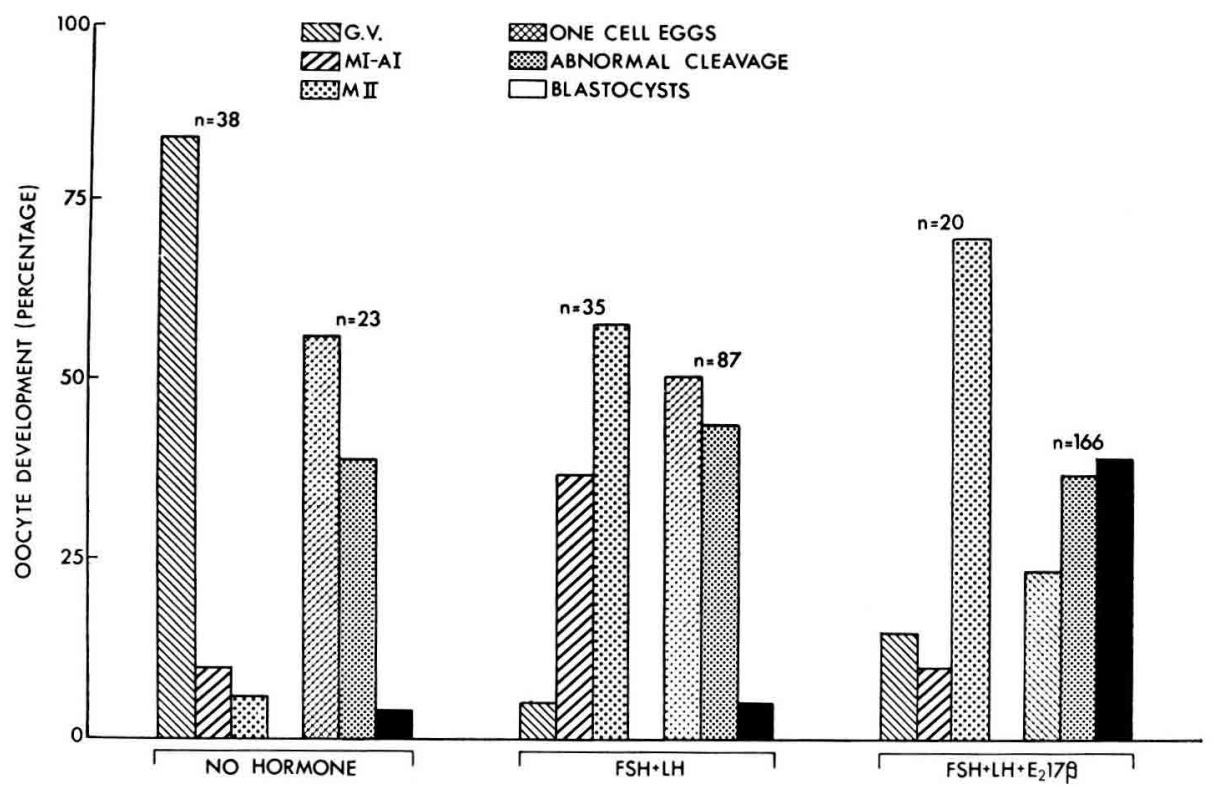

FIG. 2. - Effect of FSH (2 $\mu \mathrm{g} \mathrm{NIH-S8/ml),} \mathrm{LH} \mathrm{(1 \mu g} \mathrm{NIH-S18/ml)} \mathrm{and} \mathrm{oestradiol-17} \beta(1 \mu \mathrm{g} / \mathrm{ml})$ on meiosis and on the subsequent development of ovine oocytes cultured in intact follicles for $24 \mathrm{~h}$ before transfer to the oviducts of inseminated ewes in ostrus. 
No oocytes developed to the second metaphase in the absence of gonadotrophin ; in the presence of FSH $(2 \mu \mathrm{g} \mathrm{NIH-FSH} \mathrm{S9/mI)} \mathrm{and} \mathrm{LH}(1 \mu \mathrm{g} \mathrm{NIH-LH} \mathrm{S18} / \mathrm{ml}), 11$ p. 100 of oocytes had progessed as far as metaphase I, 26 p. 100 to anaphase I, and 58 p. 100 to metaphase II during culture. The inclusion of œstradiol-17 $\beta(1 \mu \mathrm{g} / \mathrm{ml})$ with the gonadotrophins resulted in 5 p. 100 of metaphase I, 5 p. 100 of anaphase I and 70 p. 100 of metaphase II configurations. Our recent experiments indicate that intrafollicular oocytes cultured in the presence of gonadotrophin and amino-glutethimide develop readily to metaphase I but are blocked in a high percentage of cases during the subsequent phases of meiotic maturation.

The above results are interpreted as showing that steroids are probably not involved in either the breakdown of the germinal vesicle or the formation of the metaphase I spindle. A possible involvement of steroids in the later stages of meiotic maturation cannot be excluded.

Steroids and full oocyfe maturation.

That steroids are essential for full maturation (i.e. maturation compatible with subsequent normal embryonic development to term) is demonstrated by the developmental potential of oocytes cultured in the presence or absence of added cestradiol$17 \beta$ (fig. 2). In the absence of added cstradiol-17 $\beta$ less than 5 p. 100 of oocytes developed to blastocysts despite the fact that meiosis had progressed to metaphase II in about 60 p. 100 of oocytes during culture. The effect of adding œstradiol-17 $\beta$ to the medium was seen most clearly during post-maturational development ; abnormalities associated with fertilization and cleavage were significantly reduced and the percentage of fully differentiated blastocysts increased sevenfold by adding œstradiol$17 \beta$ to the medium during maturation.

The role of steroids in the full maturation of ovine oocytes has been demonstrated further by experiments in which follicular steroidogenesis was inhibited in vitro by aminoglutethimide (Moor, Polge and Willadsen, unpublished observations). Oocytes matured in the presence of gonadotrophin and aminoglutethimide become penetrated by sperm when transferred to the oviducts of inseminated females. However, abnormalities in the formation of the male pronucleus and in the block to polyspermy occurred in almost all oocytes matured in steroidogenically inactivated follicles.

\section{Discussion.}

Progestins act as essential mediators of the action of gonadotrophins during the maturation of oocytes in amphibia and fishes (Schuetz, 1974 ; Smith, 1975 ; Jalabert, 1976). The results presented in this paper suggest that steroids play a similar role in the maturation of mammalian oocytes. It is, however, clear that these hormones are not the final or sole mediators of gonadotrophin-induced maturation since steroids alone cannot induce maturational change in the nucleus or cytoplasm of mammalian oocytes (Moor and Warnes, unpublished observations).

The means by which exogenous œstrogen facilitates the full maturation of oocytes in vitro is difficult to define, particularly since the endogenous concentration of cstrogen in culfured follicles is many times greater than that observed in the preovulatory 
follicle in vivo. It is conceivable that œstrogen levels in the follicular fluid are not an accurate reflection of the functional levels available to the oocyte. Alternatively, it is possible that high levels of œstrogen are critical during the very earliest stages of maturation when steroid levels in the culture medium are low ; exogenous cestrogen may overcome any such temporary deficiency. The identification of cstrogen-dependent factors within the oocyte would provide a valuable guide to the role of ostrogen during maturation. Our attempts to identify proteins whose synthesis is steroid dependent have, however, not yet been successful.

The role of androgens and progestins in the maturation of mammalian oocytes is unclear. Steroids of both types have been implicated in the synthesis of male pronucleus growth factor (MPGF) in oocytes from rabbits and humans (Soupart, 1973 ; Thibault, Gerard and Menezo, 1975). In addition, the experiments of McGaughey (1977) suggest that the incidence of chromosomal abnormality in pig oocytes during maturation is significantly reduced by the inclusion of progesterone and œstrogen in the culture medium. That steroids may facilitate changes not only in the cytoplasm but also in the nucleus during the late stages of meiosis is a possibility that warrants further study.

$27^{e}$ Congrès international des Sciences physiologiques,

Symposium « Germ and somatic cell interaction »

Paris, 21-23 juillef 1977.

Acknowledgments. - I thank Mr David Green for skilled analytical assistance and my colleagues Drs C. Polge, A. O. Trounson, S. M. Willadsen and G. M. Warnes for permission to refer to unpublished results. Pituitary gonadotrophins were the generous gift of the Endocrine Study Section, National Pituitary Agency, National Institutes of Health, Bethesda.

Résumé. La maturation complète des ovocytes de brebis nécessite une phase d'induction de 6 à $8 \mathrm{~h}$ à l'intérieur du follicule stimulé par les gonadotropines. La fonction stéroïdienne pendant cette phase se caractérise :

- par une sécrétion élevée d'œstrogènes $(21,0 \mathrm{nmol} / \mathrm{ml}$ de fluide folliculaire in vitro et $3,1 \mathrm{nmol} / \mathrm{ml}$ in vivo) ;

- par une production modérée d'androgènes $(7 \mathrm{nmol} / \mathrm{ml}$ in vitro; $3,5 \mathrm{nmol} / \mathrm{ml}$ in vivo) ; - et par des taux relativement bas de progestérone $(0,4 \mathrm{nmol} / \mathrm{ml}$ in vitro $; 0,8 \mathrm{nmol} / \mathrm{ml}$ in vivo).

La rupture de la vésicule germinative ef la formation de la première plaque métaphasique ne sont pas stéroïdodépendantes, mais l'implication possible des stéroïdes dans les derniers stades de la maturation méiotique est envisagée.

La maturation cytoplasmique, quant à elle, nécessite la présence de stéroïdes, en particulier d'œstrogènes. Un apport stéroïdien inapproprié pendant cette maturation entraîne des anomalies de fécondation, un retard de segmentation et une quasi-impossibilité de différenciation cellulaire et de formation du blastocyste.

\section{References}

BAE I. H., FOOTE R. H., 1975. Effects of hormones on the maturation of rabbit oocytes recovered from follicles of various sizes. J. Reprod. Fert., 42, 357-360.

JALABERT B., 1976. In vitro maturation and ovulation in rainbow trout (Salmo gairdneri), northern pike (Esox lucius) and goldfish (Carassius auratus). J. Fish Res. Board Can., 33, 974-988. 
LIEBERMAN M. E., TSAFRIRI A., BAUMINGER S., COLLINS W. P., AHRÉN K., LINDNER H. A., 1976. Oocytic meiosis in cultured rat follicles during inhibition of steroidogenesis. Acta endocr. $(K b h) ., 83,151-157$.

LINDNER H. R., TSAFRIRI A., LIEBERMAN M. E., ZOR U., KOCH, Y., BAUMINGER S., BARNEA A., 1974. Gonadotrophin action on cultured Graafian follicles : induction of maturation division of the mammalian oocyte and differentiation of the luteal cell. Recent Progr. Horm. Res., 30, 79-127.

Mc GAUGHEY R. W., 1977. The culture of pig oocytes in minimal medium, and the influence of progesterone and estradiol-17 $\beta$ on meiotic maturation. Endocrinology, 100, 39-45.

MOOR R. M., 1977. Sites of steroid production in ovine Graafian follicles in culture. J. Endocr., 73, 143-150.

MOOR R. M., TROUNSON A. O., 1977. Hormonal and follicular factors affecting maturation of sheep oocytes in vitro and their subsequent developmental capacity. J. Reprod. Fert., 49, 101-109

MOOR R. M., WARNES G. M., 1977. Regulation of oocyte maturation in mammals. In LAMMING G. E., CRIGHTON D. B., Control of ovulation, Butterworths, London (in press).

ROBERTSON J. E., BAKER R. D., 1969. Role of female sex steroids as possible regulators of oocyte maturation. Soc. Study Reprod. 2nd Annual Meeting, Davis California, Abst. No. 57, p. 27.

SCHUETZ A. W., 1974. Role of hormones in oocyte mafuration. Biol. Reprod., 10, 150-178.

SMITH L. D., 1975. Molecular events during oocyte maturation, 1-46. In WEBER R., Biochemistry of animal development, Vol. 3, Acad. Press, New-York.

SOUPART P., 1973. The need for capacitation of human sperm ; functional and ultrastructural observations, 407-434. In HAFEZ E. S. E., THIBAULT C., Biology of spermatozoa. Transport, survival and fertilizing ability, Coll. INSERM, Vol. 26, Inserm, Paris.

THIBAULT C., GÉRARD M., MÉNÉZO Y., 1975. Acquisition par l'ovocyte de lapine ef de veau du facteur de décondensation du noyau du spermatozoïde fécondant (MPGF). Ann. Biol. anim. Bioch. Biophys., 15, 705-714.

THIBAULT C., 1977. Are follicular maturation and oocyte maturation independent processes ? J. Reprod. Fert., 51, 1-15. 